\title{
Peningkatan Hasil Belajar Matemtika Siswa melalui Model Problem Based Learning
}

\author{
Abdulbari Aang1,*, Himni Muhaemin ${ }^{2}$ \\ 1,2 SMA Negeri 1 Cianjur \\ *abdulbarigasol@gmail.com
}

\begin{tabular}{|l|l|l|l|}
\hline Received : 09-07-2020 & Revised: 01-11-2020 & Accepted: 09-11-2020 & Published: 05-12-2020 \\
\hline
\end{tabular}

\begin{abstract}
ABSTRAK
Penelitian bertujuan untuk meningkatkan hasil belajar matematika siswa melalui model Problem Based Learning. Jenis penelitian PTK (Penelitian Tindakan Kelas). Subyek penerima tindakan adalah siswa kelas X 1 SMA Negeri 1 Cianjur yang berjumlah 35 siswa. Pengumpulan data yang digunakan adalah metode observasi, metode tes, metode dokumentasi dan catatan lapangan. Teknik analisis data yang digunakan adalah proses analisis data, penyajian data, dan verifikasi data. Untuk menjamin keabsahan data digunakan teknik triangulasi. Hasil penelitian menunjukkan adanya peningkatan hasil belajar matematika siswa pada pokok bahasan Logaritma. Hal ini dapat dilihat dari : 1) Ketuntasan belajar siswa sebelum adanya tindakan sebanyak 9 siswa $(39,13 \%)$ dan diakhir tindakan mencapai 19 siswa $(82,64 \%)$, 2) Keberanian siswa menanyakan materi yang belum jelas sebelum tindakan yaitu sebanyak 5 siswa $(21,74 \%)$ dan di akhir tindakan mencapai 15 siswa $(65,24 \%), 3)$ Siswa yang menanggapi pendapat siswa lain sebelum tindakan yaitu sebanyak 2 siswa $(8,69 \%)$ dan di akhir tindakan mencapai 11 siswa $(47,82 \%), 4)$ Antusias siswa mengerjakan soal sebelum tindakan yaitu sebanyak 8 siswa $(34,78 \%)$ dan di akhir tindakan mencapai 17 siswa (73,93\%). Kesimpulan penelitian ini adalah dengan implementasi model Problem Based Learning dapat meningkatkan hasil belajar matematika siswa pada pokok bahasan Logaritma.
\end{abstract}

Kata Kunci: hasil belajar, problem based learning

\section{ABSTRACT}

Learning Research to Improve Student Learning Outcomes through the Implementation of Problem Based Learning Model. Type of CAR (Classroom Action Research). The subject of the recipient of the action was a class X 1 student at Senior High School 1 Cianjur who received 35 students. Data collection used is the method of observation, test methods, methods of collection and field notes. Data analysis technique used is the process of data analysis, data presentation, and data verification. To ensure the validity of the data triangulation techniques are used. The results showed an increase in student mathematics learning outcomes on the subject of Logarithms. This can be seen from: 1) completeness of student learning before there are as many as 9 students (39.13\%) and at the end of the action reaches 19 students (82.64\%), 2) Romanian students ask for unclear material before acting according to the amount 5 students (21.74\%) and at the end of the action reached 15 students $(65.24 \%)$, 3) Students who agreed to other opinions before the action were 2 students (8.69\%) and at the end of the action reached 11 students (47, 82\%), 4) Enthusiastic students do the questions before the action that is as many as 8 students (34.78\%) and at the end of the action reaches 17 students (73.93\%). The conclusion of this research is the implementation of the Problem Based Learning model. can improve student mathematics learning outcomes on the subject of Logarithms.

Keywords: learning outcomes, problem based learning 


\section{PENDAHULUAN}

Sekolah merupakan suatu tempat terlaksananya proses belajar dan mengajar. Proses belajar mengajar dapat terlaksana dengan proses pendidikan yang bertahap dengan berbagai elemen penting di dalamnya (Sugiarni \& Ifanda, 2020). Pendidikan merupakan suatu elemen penting bahkan dibutuhkan untuk mencapai berbagai tujuan hidup dalam proses pembelajaran. Mempelajari ilmu sains, khususnya fisika, dan matematika yang hendaknya mencakup ketiga hakikat sains, sehingga siswa dapat mengembangkan diri dan bermaanfaat dikemudian hari (Maskur et al., 2020).

Standar Proses dan Standar Kompetensi Lulusan menjadi acuan bagi guru dalam melaksanakan kegiatan pembelajaran di sekolah. Standar Proses merupakan kriteria mengenai pelaksanaan pembelajaran pada satuan pendidikan untuk mencapai Standar Kompetensi Lulusan sedangkan Standar Kompetensi Lulusan (SKL) merupakan kriteria mengenai kualifikasi kemampuan lulusan yang mencakup sikap, pengetahuan, dan keterampilan (Depdiknas, 2016).

Perkembangan proses pembelajaran dari tahun ke tahun semakin berubah dan berkembang dengan model, motode dan strategi maupun pendekatan pembelajaran yang membantu proses pembelajaran. Kurikulum Nasional (Kurnas) 2013 adalah suatu kompas yang membantu melaksanakan proses pendidikan pada masa kini dengan prinsip dan komponen RPP yang termuat dalam (Permendikbud Nomor 21 Tahun 2016 tentang standar proses). Pada Rencana Pelaksanaan Pembelajaran (RPP), guru perlu menerapkan pendekatan saintifik melalui proses yang cukup lama untuk menerapkan semua kegiatan inti 5M yang dibantu juga oleh model pembelajaran yakni, discovery/inquiry learning, Problem Based Learning, dan project based learning dengan metode ceramah, eksperimen dan metode lainnya untuk menunjang proses pembelajaran (Kemdikbud, 2015; Vusparatih, 2014).

Pembelajaran matematika yang berlangsung saat ini mayoritas guru masih menggunakan metode pembelajaran konvensional yang jarang sekali mengajak siswanya untuk mengembangkan kemampuan dirinya dalam kehidupan sehari-hari (Septian, Darhim, \& Prabawanto, 2020). Akibat dari pembelajaran seperti ini siswa mengalami kesulitan dalam menangkap konsep matematika yang diajarkan oleh guru, karena didalam kegiatan belajar mengajar pengetahuan diberikan begitu saja tanpa dikaitkan dengan pengalamanpengalaman siswa sebelumnya dan tidak memperhatikan konteks dimana siswa berada pada saat proses pembelajaran berlangsung (Turiman, 2018). Mengajar hanya merupakan transfer pengetahuan dari guru ke murid. Dengan pembelajaran matematika yang seperti 
ini, siswa akan belajar matematika hanya dengan cara menghafal dan sekedar mengingat rumus (Anggriani \& Septian, 2019; Tsany, Septian, \& Komala, 2020). Padahal matematika lebih bersifat abstrak, sehingga dengan pembelajaran dengan menghafal dan mengingat sesuatu yang abstrak, menjadikan matematika akan terkesan lebih sulit dan membosankan serta menjadikan prestasi belajar matematika siswa pada umumnya rendah (As'ari, Mahmudi, \& Nuerlaelah, 2017; Utami, Mardiyana, \& Triyanto, 2019).

Berdasarkan pemaparan di atas, pembelajaran matematika ditekankan pada keterkaitan antara konsep-konsep dengan pengalaman anak sehari-hari. Selain itu, perlu menerapkan kembali konsep yang telah dimiliki anak pada kehidupan sehari-hari atau pada bidang lain sangat penting dilakukan (Fitria, Kartasasmita, \& Supianti, 2019). Salah satu pembelajaran fungsi komposisi dan fungsi invers yang berorientasi pada pengalaman sehari-hari (everyday experience) dan menerapkan fungsi komposisi dan fungsi invers dalam kehidupan sehari-hari adalah pembelajaran berbasis masalah (Problem Based Learning).

Berkaitan dengan hal tersebut di atas, salah satu cara untuk dapat menciptakan sumber daya manusia berkualitas, guru dalam mengajar dapat menggunakan beberapa metode dan pendekatan. Dalam hal ini, pendekatan yang dianggap sesuai dengan perkembangan Ilmu Matematika adalah Problem Based Learning , karena dalam belajar berdasarkan masalah, pembelajaran didesain dalam bentuk pembelajaran yang diawali dengan struktur masalah real yang berkaitan dengan konsep-konsep fungsi komposisi dan fungsi invers yang akan dibelajarkan. Pembelajaran dimulai setelah siswa dikonfrontasi dengan struktur masalah real, dengan cara ini siswa mengetahui mengapa mereka belajar. Semua informasi akan mereka kumpulkan melalui penelaahan materi ajar, kerja praktik lab ataupun melalui diskusi dengan teman sebayanya, untuk dapat digunakan memecahkan masalah yang dihadapinya. Diharapkan pembelajaran yang terjadi dapat lebih bermakna dan memberi kesan yang kuat kepada siswa sehingga dapat meningkatkan motivasi dalam pembelajaran matematika (Muhammad, Septian, \& Sofa, 2018).

\section{METODE PENELITIAN}

Metode pada penelitian ini adalah Penelitian Kualitatif dengan desain Hopkins (Sutama, Narimo, \& Samino, 2015) menyatakan bahwa Penelitian Tindakan Kelas (PTK) yaitu penelitian yang mengkombinasikan prosedur penelitian dengan tindakan subtantif, tindakan yang dilakukan dalam disiplin inquari, atau suatu usaha seseorang untuk memahami apa yang sedang terjadi, sambil terlibat dalam sebuah proses perbaikan dan 
perubahan. Penelitian ini dilakukan pada siswa kelas X SMA Negeri 1 Cianjur tahun ajaran 2015/2016 yang berjumlah 35 siswa. Penelitian dilaksanakan secara bertahap. Adapun tahapan pelaksanaan penelitian adalah sebagai berikut:

a. Tahap Persiapan dilaksanakan pada bulan April - Mei 2015.

b. Tahap Pelaksanaan dilaksanakan pada bulan Agustus 2015.

c. Tahap Pengumpulan data dilaksanakan pada bulan Oktober 2015.

d. Laporan dilaksanakan pada bulan November 2015

Penelitian tindakan kelas menerapkan prinsip perbaikan terus menerus terhadap proses pembelajaran, dari perbaikan tersebut akan meningkatkan kualitas pembelajaran di kelas. Penelitian tindakan merupakan kegiatan pemecahan masalah yang dimulai dari: 1) dialog awal; 2) Perencanaan tindakan; 3) Pelaksanaan; 4) Pengamatan; 5) Refleksi; 6) Penyimpulan data.

Langkah-langkah persiapan yang dilakukan peneliti untuk mengadakan tindakan adalah mengidentifikasi masalah, mengidentifikasi siswa dan perencanaan solusi masalah yang diharapkan dapat digunakan untuk mengatasi permasalahan yang dihadapi oleh siswa terutama yang berhubungan dengan hasil belajar siswa dalam belajar matematika. Pelaksanaan tindakan dilaksanakan berdasarkan pada perencanaan, dari perencanaan yang ada diimplementasikan dengan menerapkan model Problem Based Learning . Pelaksanaan tindakan dilaksanakan berdasarkan pada perencanaan namun, tindakan tidak mutlak dikendalikan oleh rencana. Tindakan yang nantinya diputuskan mengandung resiko karena terjadi dalam situasi nyata. Maka dari itu rencana tindakan harus tentatif dan sementara, fleksibel, dan siap diubah sesuai dengan keadaan yang ada sebagai usaha kearah perbaikan.

Pengumpulan data didapat dari beberapa kegiatan dengan menggunakan teknik pengumpulan data, yaitu : (1) Tes dilakukan setelah materi selesai diberikan berguna untuk mengetahui tingkat kemampuan siswa dalam memahami materiyang diajarkan, (2) observasi digunakan untuk mengamati siswa dan guru secara langsung dalam interaksi pelajaran matematika, (3) dokumentasi digunakan untuk memperoleh data sekolah SMA Negeri 1 Cianjur dan identitas siswa antara lain nama siswa dan nomor induk siswa, serta foto rekaman proses tindakan penelitian, (4) catatan lapangan digunakan sebagai pertimbangan dalam pelaksanaan putaran selanjutnya untuk menimalkan permasalahan dari putaran sebelumnya.

Penerapan model Problem Based Learning ini diaplikasikan pada materi fungsi komposisi dan fungsi invers pada siswa kelas X SMA Negeri 1 Cianjur dengan melibatkan guru mata pelajaran matematika kelas X. Pada penelitian tindakan kelas ini, data dianalisis 
sejak tindakan pembelajaran dilakukan dan dikembangkan sejak refleksi sampai proses penyusunan laporan. Sutama (2010:100-101) menyatakan bahwa analisis data dalam penelitian ini dilakukan menggunakan metode alur yaitu meliputi : (1) Proses analisis data, merupakan proses menyeleksi data dari beberapa sumber kemudian menentukan fokus, meringkas, menyusun, dan mengubah bentuk data yang ada ke dalam catatan lapangan. (2) Penyajian data, penyajian data dilakukan dalam rangka pemahaman terhadap sekumpulan informasi yang memberi kemungkinan adanya penarikan kesimpulan. (3) Verifikasi data, verifikasi data ini dilakukan secara bertahap untuk memperoleh derajat kepercayaan yang tinggi. Dengan demikian langkah analisis data dalam penelitian tindakan ini dilakukan sejak tindakan dilakukan.

Analisis hasil pada penelitian ini ditekankan hasil belajar siswa. Hasil belajar ini dapat dilihat dari ketuntasan siswa yang mencapai KKM dengan nilai lebih dari sama dengan 75, keaktifan bertanya kepada guru tentang materi yang belum jelas, keberanian menanggapi pendapat siswa lain, dan antusias siswa mengerjakan soal yang diberikan dari guru.

\section{HASIL DAN PEMBAHASAN}

Hasil kolaborasi pelaksanaan tindakan kelas yang dilaksanakan oleh guru matematika kelas X SMA Negeri 1 Cianjur bersama peneliti dengan menerapkan model Problem Based Learning dapat meningkatkan hasil belajar siswa dalam proses pembelajaran matematika. Peningkatan hasil belajar siswa terlihat saat proses pembelajaran, terbukti dari adanya peningkatan siswa yang mencapai batas tuntas dengan KKM nilai lebih dari sama dengan 75 , keaktifan bertanya kepada guru tentang materi yang belum jelas, keberanian siswa menanggapi pendapat siswa lain dan antusias siswa mengerjakan soal yang diberikan dari guru. Data yang diperoleh mengenai hasil belajar siswa sebelum dilakukan tindakan sampai putaran III secara keseluruhan ditunjukkan pada Gambar 1. 


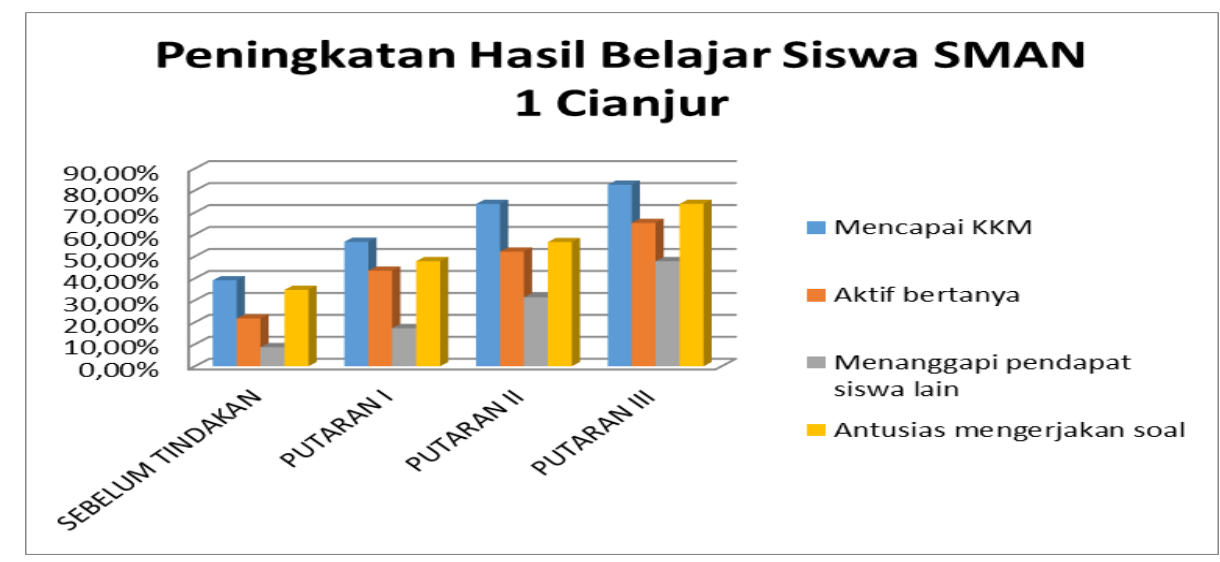

Gambar 1. Grafik Peningkatan Hasil Belajas Siswa Kelas X SMAN 1 Cianjur

Pada Gambar 1, hasil belajar dalam penelitian ini yaitu pertama ketuntasan belajar siswa. Ketuntasan belajar siswa ini dimaksudkan jika siswa sudah mencapai Kriteria Ketuntasan Minimal (KKM) dengan nilai lebih dari sama dengan 75 maka siswa dikatakan tuntas dan sudah mencapai hasil belajar yang baik. Siswa dikatakan tuntas belajar dalam setiap putaran jika mencapai KKM dengan nilai $\geq 75$ dari seluruh soal yang diberikan. Nilai siswa yang belum mencapai KKM akan remidial dan yang sudah mencapai KKM diberikan pengayaan. Kedua keaktifan bertanya, siswa aktif dalam bertanya tentang materi yang belum dipahami kepada guru ini dimaksudkan jika keaktifan bertanya siswa meningkat atau jumlah siswa yang bertanya meningkat maka bisa dikatakan hasil belajar meningkat. Ketiga keberanian siswa dalam menanggapi pendapat siswa lain, jika siswa semakin berani saling menanggapi pendapat antar siswa lain maka bisa dikatakan hasil belajar meningkat. Keempat adalah antusias mengerjakan soal dari guru, ini dimaksudkan jika siswa semakin antusias dan aktif mengerjakan soal dari guru maka hasil belajar matematika siswa pun bisa meningkat.

Pembahasan berisi tentang uraian dan penjelasan mengenai hasil tindakan kelas. Pada pembehasan ini akan membahas penelitian yang telah dilakukan oleh peneliti dan peneliti terdahulu. Pembahasan antar putaran mengenai peningkatan hasil belajar siswa yaitu membandingkan apakah terjadi peningkatan dari sebelum tindakan kelas sampai tindakan kelas Putaran III.

Penerapan model Problem Based Learning dapat meningkatkan hasil belajar siswa kelas X SMA 1 Cianjur pada pelajaran matematika. Hal ini dapat dilihat dari meningkatnya ketuntasan belajar siswa dengan KKM nilai lebih dari sama dengan 75, keaktifan bertanya kepada guru tentang materi yang kurang jelas, keberanian menenggapi pendapat siswa lain dan antusias mengerjakan soal dari guru (Suryawan \& Permana, 2020). Dampak pembelajaran yang aktif dan menyenangkan, maka hasil belajar siswa juga mengalami 
peningkatan (Fatwa, Septian, \& Inayah, 2019). Begitupun dengan beberapa hasil penelitian sebelumnya yang menyatakan bahwa dengan menggunakan model problem based learning akan meningkatkan hasil belajar matematika pada siswa di sekolah (Amalia, Purwaningsih, Widodo, \& Fasha, 2020; Julyanasari, Praja, Noto, Sunan, \& Djati, 2019; Septian \& Komala, 2019).

Peningkatan hasil belajar siswa pada setiap putaran juga dapat dilihat dari; 1) Ketuntasan belajar siswa sebelum adanya tindakan sebanyak 9 siswa $(39,13 \%)$ dan di akhir tindakan mencapai 19 siswa $(82,64 \%)$, 2) Keberanian siswa menanyakan materi yang belum jelas sebelum tindakan yaitu sebanyak 5 siswa $(21,74 \%)$ dan di akhir tindakan mencapai 15 siswa $(65,24 \%), 3)$ Siswa yang menanggapi pendapat siswa lain sebelum tindakan yaitu sebanyak 2 siswa $(8,69 \%)$ dan di akhir tindakan mencapai 11 siswa $(47,82 \%), 4)$ Antusias siswa mengerjakan soal sebelum tindakan yaitu sebanyak 8 siswa $(34,78 \%)$ dan di akhir tindakan mencapai 17 siswa (73,93\%). Kesimpulan penelitian ini adalah dengan implementasi model Problem Based Learning dapat meningkatkan hasil belajar matematika siswa pada pokok bahasan Logaritma.

\section{KESIMPULAN}

Hasil penelitian tindakan kelas yang dilakukan secara kolaboratif antara peneliti dengan guru matenatika kelas X 1 SMA Negeri 1 Cianjur dalam pembelajaran matematika melalui penerapan model Problem Based Learning untuk meningkatkan hasil belajar matematika, dapat diambil kesimpulan bahwa implementasi model Problem Based Learning dapat meningkatkan hasil belajar matematika siswa.

\section{REFERENSI}

Amalia, S. R., Purwaningsih, D., Widodo, A. N. A., \& Fasha, E. F. (2020). Model Problem Based Learning Berbantuan GeoGebra dan Model Realistic Mathematics Education terhadap Representasi Matematis Siswa ditinjau dari Gaya Kognitif. Jurnal Elemen, 6(2), 157-166. https://doi.org/10.29408/jel.v6i2.1692

Anggriani, A., \& Septian, A. (2019). Peningkatan Kemampuan Komunikasi Matematis dan Kebiasaan Berpikir Siswa Melalui Model Pembelajaran IMPROVE. IndoMath: $\begin{array}{llll}\text { Indonesia Mathematics } & \text { Education, }\end{array}$ https://doi.org/10.30738/indomath.v2i2.4550

As'ari, A. R., Mahmudi, A., \& Nuerlaelah, E. (2017). Our prospective mathematic teachers are not critical thinkers yet. Journal on Mathematics Education, 8(2), 145-156. https://doi.org/10.22342/jme.8.2.3961.145-156

Depdiknas. (2016). permendikbud No.23 tahun 2016. In NO. 23 Tahun 2016. https://doi.org/http://dx.doi.org/10.1016/j.athoracsur.2009.09.030

Fatwa, V. C., Septian, A., \& Inayah, S. (2019). Kemampuan Literasi Matematis Siswa 
melalui Model Pembelajaran Problem Based Instruction. Mosharafa: Jurnal Pendidikan Matematika, 8(3), 389-398.

Fitria, M., Kartasasmita, B., \& Supianti, I. I. (2019). Analisis Kemampuan Pemahaman Konsep Matematis Siswa yang Menggunakan Model Pembelajaran Reciprolcal Teaching. Jurnal Prisma, 8(2), 124-134.

Julyanasari, N., Praja, E. S., Noto, M. V., Sunan, U., \& Djati, G. (2019). Problem Based Learning Model on The Ability of Students Mathematical Connection. PRISMA, 8(2), 167-172. https://doi.org/10.35194/jp.v8i2.400

Kemdikbud. (2015). Materi Pelatihan guru Implementasi Kurikulum. Materi Pelatihan Guru Implementasi Kurikulum 2013, (Jakarta, PSDMPK-PMP 2015), 2015.

Maskur, R., Sumarno, Rahmawati, Y., Pradana, K., Syazali, M., Septian, A., \& Palupi, E. K. (2020). The effectiveness of problem based learning and aptitude treatment interaction in improving mathematical creative thinking skills on curriculum 2013. European Journal of Educational Research, 9(1), 375-383. https://doi.org/10.12973/eu-jer.9.1.375

Muhammad, G. M., Septian, A., \& Sofa, M. I. (2018). Penggunaan Model Pembelajaran Creative Problem Solving untuk Meningkatkan Kemampuan Pemecahan Masalah Matematis Siswa. Mosharafa: Jurnal Pendidikan Matematika, 7(3), 315-326. https://doi.org/10.31980/mosharafa.v7i3.140

Septian, A., Darhim, \& Prabawanto, S. (2020). Mathematical representation ability through geogebra-assisted project- based learning models. Journal of Physics: Conference Series, 1657(1), 12019. https://doi.org/10.1088/1742-6596/1657/1/012019

Septian, A., \& Komala, E. (2019). Kemampuan Koneksi Matematik dan Motivasi Belajar Siswa dengan Menggunakan Model Problem-Based Learning (PBL) Berbantuan Geogebra di SMP. PRISMA, 8(1), 1-13. https://doi.org/10.35194/jp.v8i1.438

Sugiarni, R., \& Ifanda, A. R. (2020). Peningkatan Keaktifan Mahasiswa pada Perkuliahan Sejarah dan Filsafat Matematika melalui Model Pembelajaran Auditory Intellectually Repetition. Prisma, 9(1), 57. https://doi.org/10.35194/jp.v9i1.387

Suryawan, I. P. P., \& Permana, D. (2020). Media Pembelajaran Online Berbasis Geogebra sebagai Upaya Meningkatkan Pemahaman Konsep Matematika. Prisma, 9(1), 108. https://doi.org/10.35194/jp.v9i1.929

Sutama, S., Narimo, S., \& Samino, S. (2015). Management Of Curriculum 2013 Mathematic Learning Evaluation In Junior High School. International Journal of Education, 7(3), 164. https://doi.org/10.5296/ije.v7i3.8335

Tsany, U. N., Septian, A., \& Komala, E. (2020). The ability of understanding mathematical concept and self-regulated learning using macromedia flash professional 8. Journal of Physics: Conference Series, 1657, 12074. https://doi.org/10.1088/17426596/1657/1/012074

Turiman, T. (2018). Pengaruh Pembelajaran Dengan Metode Demontrasi Terhadap Kemampuan Berpikir Kreatif Dan Koneksi Matematik Serta Motivasi Belajar Siswa Smp. Prisma, 7(2), 206. https://doi.org/10.35194/jp.v7i2.374

Utami, C. T. P., Mardiyana, \& Triyanto. (2019). Profile of students' mathematical representation ability in solving geometry problems. IOP Conference Series: Earth and Environmental Science, 243(1). https://doi.org/10.1088/1755-1315/243/1/012123

Vusparatih, D. S. (2014). Peranan Komunikasi Guru dalam Implementasi Kurikulum 2013. Humaniora, 5(1), 387. https://doi.org/10.21512/humaniora.v5i1.3037 